\title{
Entrepreneurial Self-efficacy and Entrepreneurial Intention among Polytechnic Students Involved and Not Involved in Entrepreneurship Education
}

\author{
Norasmah Othman ${ }^{1}$, Nur Sa'adah Mohd Hisam² \\ ${ }^{1}$ Faculty of Education, Universiti Kebangsaan Malaysia, Malaysia \\ ${ }^{2}$ Politeknik Sultan Salahuddin Abdul Aziz Shah, Persiaran Usahawan, Seksyen U1, Malaysia
}

Received May 12, 2020; Revised August 8, 2020; Accepted August 28, 2020

\section{Cite This Paper in the following Citation Styles}

(a): [1] Norasmah Othman, Nur Sa'adah Mohd Hisam, "Entrepreneurial Self-efficacy and Entrepreneurial Intention among Polytechnic Students Involved and Not Involved in Entrepreneurship Education," Universal Journal of Educational Research, Vol. 8, No. 10, pp. 4406-4415, 2020. DOI: 10.13189/ujer.2020.081007.

(b): Norasmah Othman, Nur Sa'adah Mohd Hisam (2020). Entrepreneurial Self-efficacy and Entrepreneurial Intention among Polytechnic Students Involved and Not Involved in Entrepreneurship Education. Universal Journal of Educational Research, 8(10), 4406-4415. DOI: 10.13189/ujer.2020.081007.

Copyright $\bigcirc 2020$ by authors, all rights reserved. Authors agree that this article remains permanently open access under the terms of the Creative Commons Attribution License 4.0 International License

\begin{abstract}
Entrepreneurship is a field being focused on by all educational institutions, including polytechnic institutions. Various plans and strategies have been designed to encourage the involvement of students in entrepreneurship. Until now, it has been reported that students' participation in entrepreneurship, particularly the polytechnic students, is less than satisfactory. This study aims to identify the entrepreneurial self-efficacy and entrepreneurial intention levels among polytechnic students who have been actively involved in entrepreneurship education programs, compared with those who have never had any similar involvement. This study randomly distributed survey questionnaire to 317 polytechnic students across Malaysia. Responses were analyzed using descriptive statistical methods. Results showed that students who have been involved in entrepreneurship courses have a higher level of entrepreneurial self-efficacy compared to students who have never received entrepreneurship education. However, the level of entrepreneurial intention is high regardless of involvement in entrepreneurship education. Meaning, there is no significant difference in the level of entrepreneurial intention after graduating from a polytechnic institution based on students' involvement in entrepreneurship education. The findings can serve as a guideline for policy makers, curriculum developers, and polytechnic educators to improve existing plans and strategies so that they are more relevant to current needs.
\end{abstract}

Keywords Entrepreneurship Education, Entrepreneurial Intention, Entrepreneurial Self-efficacy, Polytechnic Students

\section{Introduction}

The uncertainty in the world's economy has also affected the lifestyle of individual nations. Job opportunities in Malaysia are plummeting while the number of job seekers is increasing. The country is now incapable of guaranteeing jobs for its citizens, and this is occurring all around the world. As a result, competition for positions is extremely fierce, and this requires young people to be more proactive in creating new jobs in order to have better and more secure lives. Hence, various measures and alternatives are being implemented in a wide variety of countries to ensure that their citizens do not always rely on the government for employment. One of the efforts exercised is to encourage youths to venture into the field of entrepreneurship.

National Entrepreneurship Policy 2030 (NEP2030) introduced by the Ministry of Entrepreneur Development and Cooperative on July 2019 will act as a catalyst for Malaysia's achievement as a united, prosperous and dignified country and continue to develop sustainably with 
a more equitable and inclusive economic distribution, further emerging as the axis of the Asian economy. Five key objectives that have been set under the NEP2030 are 1 . creating a holistic and conducive entrepreneurial ecosystem to support the inclusive, balanced and sustainable Malaysian socio-economic development agenda. 2. To form a Malaysian society with an entrepreneurial mindset and culture. 3. Increase the number of national entrepreneurs who are quality, viable, resilient, global-minded and competitive. 4. Enhance the capabilities of micro, small and medium enterprises and cooperatives. 5 . Make entrepreneurship a career of choice [1]. Toward achieving the national objectives, entrepreneurship can be set forth as early as primary school by incorporating and integrating entrepreneurship as a subject in school.

In education context, the Entrepreneurship Action Plan of Higher Education Institutions (2016-2020) that was launched by the Ministry of Higher Education (MoHE) outline two strategies to be focused on: 1) develop a holistic and comprehensive curriculum and; 2) enhancing the learning support system [2]. Generally, this policy serves as an official foundation for the efforts and initiative to incorporate the value and skills of entrepreneurship among Malaysian including students at public universities, polytechnic institutions, and community colleges.

At the polytechnic level, the Department of Polytechnic and Community College Education (DPCCE) has incorporated an entrepreneurship course as a compulsory subject for polytechnic diploma students as a way to provide well-organized and holistic entrepreneurship education. As for commerce department, a digital entrepreneurship course was set as elective course in addition to compulsory entrepreneurship course. The curriculum that was been improvised every 5 years has been carried out together with workshop activities, seminars, visits, and competitions related to entrepreneurship to cultivate as many students as possible into potential entrepreneurs. Besides, the entrepreneurship units within polytechnic institutions have also been restructured and required to build entrepreneurship centers in line with the requirements of the Action Plan of Higher Education Institutions [3]. The entrepreneurship centers serve as an early platform for students who are interested in venturing into entrepreneurship to learn and gain practical experience before they enter the real business world. Through these centers, the students can also practice the knowledge that they gain from the entrepreneurship courses in their respective institutions [4]. This initiative aims to expose students to the real business world and help those who are truly passionate about pursuing entrepreneurial ventures.

\section{The Challenges of Entrepreneurship in Polytechnic Malaysia}

The Department of Polytechnic and Community College Education (DPCCE), under the Ministry of Higher
Education (MoHE), set the direction of the First Phase Polytechnic Transformation in 2009. An outcome to be achieved was to produce great entrepreneurs. This transformation placed a significant responsibility on polytechnic institutions to produce graduates who would go on to create jobs instead of graduates who would simply seek jobs throughout their careers. The Graduate Tracer Study statistics 2018 showed that the percentage of polytechnic students owning a business still remained low where only $9.3 \%$ of polytechnic graduates had self-employed while the remaining $91.7 \%$ chose to work at existing public and private organization [5]. This report was in line with previous studies by $[6,7]$ which reiterated that the data of the polytechnic graduates' participation in the entrepreneurship field was still low. Hence, some questions arose, why did this happen? Some researchers even questioned whether the entrepreneurship modules offered in polytechnic institutions are still not effective $[6,8]$ or are the teaching and learning syllabi used not suitable [7]. Are there any other factors that hinder this achievement? Because of these unanswered questions, this study acknowledges that the poor results may not only be caused by the specific entrepreneurship module or teaching and learning method used and the possible existence of other factors that influence the involvement of students or graduates in this field.

In order to identify the key elements that can explain and anticipate an entrepreneur's intention, many studies have made a link between Ajzen's Organized Behavioural Theory with Bandura's Self-Efficacy Theory e.g., [9-15]. This is because self-efficacy is seen as the motivation for consistency of action or behavior among higher education institution students.

However, the discrepancies among previous findings as to whether self-efficacy is truly capable of enhancing someone's motivation to dive into the entrepreneurship field are questioned by the researcher of this study. Some studies found that entrepreneurial self-efficacy was not a factor that encouraged the entrepreneurial intention of students, while others found evidence to the contrary e.g., [10,14,16-20]. Furthermore, a study about the general relationship between entrepreneurial intention and self-efficacy among polytechnic students in Malaysia is insufficient, particularly differentiating the level of entrepreneurial intention and self-efficacy on students who were involved or not involved in entrepreneurship education. Therefore, the objectives of this study are:

1. To determine the level of entrepreneurial self-efficacy based on the involvement of students in entrepreneurship education.

2. To determine the level of entrepreneurial intention based on the student's involvement in entrepreneurship.

\section{Entrepreneurial Intention}

In cognitive psychology, intention is defined as a state of 
mind before performing an act or behavior [21]. [22] defined intention as a tendency of behavior caused by attitude. However, in entrepreneurship, intention is interpreted as an individual's state of mind to start a new business [23, 57]. Intention has been proved by psychologists to be a predictor of a behavior, attitude, and action of a trustworthy individual. The Theory of Planned Behavior was first debated by [24] through his work, "From Intentions to Actions: A Theory of Planned Behavior." This theory was built on the Theory of Reasoned Action [25], which outlined two determining factors of causal behavior, attitude and subjective norm. Attitude refers to the individual's perception of positive and negative judgment of a certain behavior, whereas subjective norm refers to the individual's perception towards social pressure or the public's view of a certain behavior [25].

The idea of Theory of Reasoned Action was then expanded into the Theory of Planned Behavior (TPB) (Figure 1) where [26] outlined an additional factor: behavior control. Behavior control refers to the perception or impression of an individual regarding how easy or difficult it is to act on a certain behavior based on previous experiences and challenges faced. [26] saw that these three factors were capable of directly influencing intentions, and intentions influenced a person's real behavior. Behavior control was also found to be positively related to the tendencies of individuals to act on the behavior.

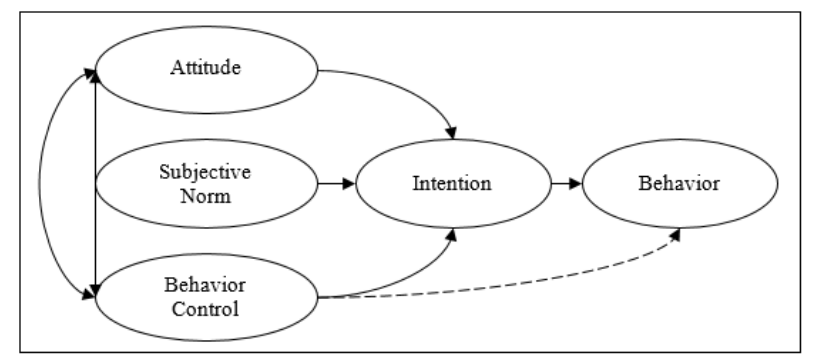

Figure 1. Ajzen's Theory of Planned Behavior

Since this theory was developed, scholars from various fields beyond entrepreneurship have adapted it to predict a certain future action or human behavior. Many previous studies applied this theory, including [20] and [21], but there were issues regarding the measuring instrument used [27]. [27] then developed an entrepreneurship intention model, which was based on the TPB as well as the instruments of entrepreneurial intention, to overcome the limitations of past instruments.

Other than [27] instruments, there are many others that can be used to measure entrepreneurial intention. One of them is the questionnaire developed by [28]. This instrument consists of four items that measure tendency, readiness, and potential of an individual to become an entrepreneur. Meanwhile, the eight-item instrument developed by [29] measures an individual's tendency to implement entrepreneurial activities over the next 12 months. [30] also developed a six-item questionnaire relating to organized behavior among young graduates and the intention to start a new business. Based on the questions to be answered, this study chose to use the instrument developed by [28] to identify the level of entrepreneurial intention because the focus of the study was similar and the sample was also students. In fact, the results of their study also found that the entrepreneurial intention has a positive correlation to a person's desire to set up a business. Since the study was in abroad, the researcher would like to identify if there is potential similar result among Malaysian Polytechnic students.

\section{Entrepreneurship Self-efficacy}

[31] further study explained the factors of behavior control in more detail and explained that the measurements of these factors needed to be related with self-efficacy and control to ensure consistency of the factors in influencing individual's tendency to execute the act or behavior. Self-efficacy, as defined by [32], refers to an individual's belief in their capability to complete a task. In the context of entrepreneurship, [9] defined self-efficacy as the level of an individual's confidence in starting a new business. It cannot be denied that this belief is an important aspect of self-motivation and behavior because it can influence an individual's life direction. This is because, according to the basis of the theory, individuals tend to choose activities they are confident in doing [32]. A study by [14] also explained that many Indonesian students are incapable of becoming entrepreneurs due to a lack of entrepreneurial self-efficacy, despite their stated intent to do so.

[15] and [10] agreed with Bandura's statement regarding individuals with high self-efficacy being more likely to show interest in executing their tasks and more willing to strive against challenges and obstacles as compared to individuals with low self-efficacy. From the perspective of entrepreneurship, [9] and [14] conclude that individuals with a high level of self-efficacy have a higher chance of venturing into entrepreneurship. The quantitative and qualitative mixed method study by [11] proved that self-efficacy positively influenced entrepreneurial intention where the finding explained that the higher the self-efficacy, the more interested the students were in becoming entrepreneurs. Their results in the line with the findings of [13] which found that entrepreneurial self-efficacy only had a moderately positive relationship with entrepreneurial intention.

[33] explained that self-efficacy was not a magic pill that could instantly inspire people to start their business. However, self-efficacy was seen as a driving element for people to be consistent in their actions towards starting a business. [34] agreed with the notion that the level of self-efficacy would not guarantee an individual to be successful in their chosen field, but asserted that self-efficacy itself was what made an individual become persistent in facing challenges in order to achieve his or her dream

Considering the potential of self-efficacy to incorporate 
interest and create a tendency towards a certain field, various instruments have been developed to measure the level of self-efficacy, specifically or generally. [35] outlined the focus of entrepreneurial self-efficacy into six dimensions:(i) developing new products and market opportunities; (ii) buildings an innovative environment; (iii) initiating investors relationship; (iv) defining core purpose; (v) coping with unexpected challenges; and (vi) developing critical human resources.

Even though there are studies using the instruments developed by [35], this instrument failed at determining the effectiveness of every dimension that influences entrepreneurial intention [36]. In addition, [35] instrument is more suitable for identifying self-efficacy amongst entrepreneurs than among students because entrepreneurship education is now more focused on cultivating entrepreneurial interest until the individual is more likely to start a new business.

The questionnaire developed by [36] is more effective in measuring the level of entrepreneurial self-efficacy among students because it uses five dimensions adapted from [37] in relation to entrepreneurial activities in starting a business: (i) searching; (ii) planning; (iii) marshalling; (iv) implementing - people; and (v) implementing - financial. This instrument was used [9] to investigate the role of gender as a moderator in the relationship between entrepreneurial self-efficacy and entrepreneurial intention among undergraduate students. This study also used the instrument developed by [36] to examine the level of entrepreneurial self-efficacy among Malaysian Polytechnic students based on the involvement of students in entrepreneurship education.

\section{Entrepreneurship Education}

[38] expanded upon his self-efficacy theory by examining four main factors that can increase self-efficacy: mastery experience, social model, social persuasion, and psychological state. A study by [20] investigated the role of entrepreneurial self-efficacy as the mediator between formal education and entrepreneurial intention. The study examined all of the four factors introduced by [38] in the context of formal education (Figure 2).

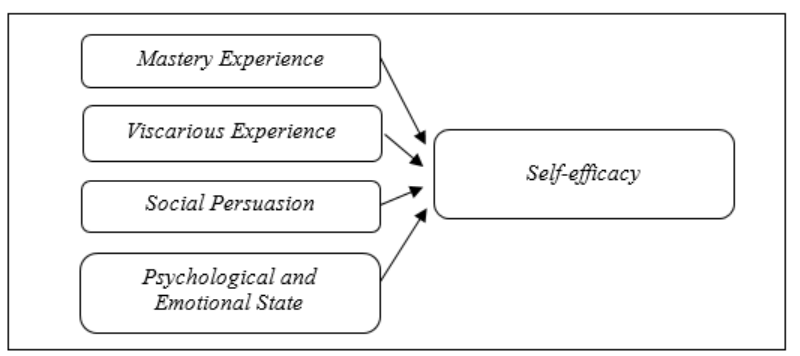

Figure 2. Bandura's Self-efficacy Theory (1986)

Mastery experience can be incorporated through training programs and entrepreneurship competitions. Entrepreneurship education provided a social model through field studies on successful entrepreneurs, knowledge sharing from entrepreneurs, and cooperation and collaboration with entrepreneurs. From the aspect of social persuasion, entrepreneurship education could also aid students psychologically to be more eager to venture into entrepreneurship by displaying examples of lifestyles and working styles of successful entrepreneurs. [20] found that formal entrepreneurial education was the fundamental factor in raising the level of self-efficacy among students compared to entrepreneurial experience and tendency to take risks.

Furthermore, scholars also searched for answers to whether entrepreneurship education could be related to and influence entrepreneurial intention directly. A study by [30] found that entrepreneurship education could influence entrepreneurial intention through the exposure of relevant skills during the education process. In other words, students were more willing and prepared to start a business after they received business and entrepreneurship-related education. Another study by [39] found that participation in entrepreneurship education had a positive impact on entrepreneurial intention. Similar conclusions were reached by [40-42] who also found that students receiving entrepreneurship education had high entrepreneurial behavioral tendencies compared to students who never attended any program related to business or entrepreneurship.

However, some studies were unable to provide conclusive evidence supporting a significant relationship between entrepreneurship education and entrepreneurial intention. Based on the three factors that influenced entrepreneurial intentions in Ajzen's Theory of Planned Behavior, a study by [43] showed no evidence that indicates entrepreneurship education could influence attitude towards the field of entrepreneurship and entrepreneurial intention. This study was in line with a study by [44] also proved that there was no significant difference in the tendency of entrepreneurial intentions between students who had participated in entrepreneurship courses and students who had not. [45] which based on the Entrepreneurship Student Readiness Model in examining the relationship between a university's environment (i.e., lecturers, curriculum and co-curricular programs, support resources, and campus cycles) and entrepreneurial intention among the entrepreneurship students. The study found that the entrepreneurship curriculum and co-curricular programs only had a weak relationship with entrepreneurial intention.

[46] showed a positive increase in entrepreneurial intention among students after their participation in entrepreneurship education. However, the study also found that entrepreneurship education was not the factor affecting the tendency of entrepreneurial intention, because these two elements needed to be taken separately from entrepreneurship self-efficacy.

There have also been studies which have used entrepreneurship education as a mediator in investigating 
the factors influencing entrepreneurial intention. [47] studied the effects of entrepreneurship education as a moderator in the relationship between innovation, tendency in taking risks, family background, entrepreneurial constraints, and environmental encouragement with the development of entrepreneurial intention. The study found that entrepreneurship education only showed a significant impact as a moderator between environmental encouragement and entrepreneurial intention. This implied that students who were exposed to entrepreneurship programs were better able to enhance their knowledge about these programs and the policies developed by the government, which helped them become entrepreneurs.

Therefore, this study examined the context of entrepreneurship education in Malaysia's polytechnic institutions, how entrepreneurship education is capable of improving the level of students' entrepreneurial self-efficacy, and whether entrepreneurship education can encourage students to be more interested in venturing into entrepreneurship.

\section{Methodology}

This study used a quantitative methodology by distributing a survey. The population of the study consisted of diploma students from 36 polytechnic institutions in Malaysia with a total of 94,642 students [3]. A total of 382 students, randomly selected were involved in this study and the sample size was determined based on a schedule developed by [48]. However, only 317 responses $(82.98 \%)$ could be used in the analysis. This feedback rate was sufficient for research purposes [49].

The questionnaire was divided into three sections: Section A (5 items) - collecting demographic information (eg: gender, institution, department of study, background of business and entrepreneurial course that has been attended); Section B - studying entrepreneurial self-efficacy (19 items); and Section C (4 items) measuring the construct of entrepreneurial intention.

The instrument for Section B was adapted from an instrument developed by [36], which encompassed the five dimensions of entrepreneurial activities based on [37] (searching; planning; marshalling; implementing - people; and implementing - financial). The questionnaire instrument by [36] was selected because all five dimensions focused on the entrepreneurial activities involved in starting a business. This instrument used a 5-point Likert scale ranging from 1 - strongly disagree - to 5 - strongly agree.

The instrument for Section C was adapted from [28] and consisted of four items measuring individual tendency to be involved in entrepreneurial venture within 5 years upon graduation. This instrument also used a 5-point scale ranging from 1 - very interested/highly considered/very willing/very likely to 5 - not at all interested/not at all willing/very unlikely, according to the questions asked. For the mean measurement of entrepreneurial intention, the scaled score for each item was reversed. The findings for Section B and C was interpreted according to [45] as shown in Table 1.

Table 1. Interpretation of mean value by [50]

\begin{tabular}{|c|c|}
\hline Mean Score & Description \\
\hline $1.00 \leq 1.89$ & Very low \\
\hline $1.90 \leq 2.69$ & Low \\
\hline $2.70 \leq 3.49$ & Moderate \\
\hline $3.50 \leq 4.29$ & High \\
\hline $4.30 \leq 5.00$ & Very High \\
\hline
\end{tabular}

Before the actual study was conducted, the instrument was put through a pilot test to confirm its validity and reliability. Validity is important because it determines whether the instrument is able to measure what the researcher intends to measure [50]. This study runs a convergence validity using an average variance extracted, factor loading and composite reliability analysis. As the result, only 15 items of entrepreneurial self-efficacy instrument can be used.

The reliability of an instrument determines the consistency of each item's score in which tested items need to produce the same score, or similar result, even if the subject is tested several times. This study relied on the Cronbach Alpha value to determine the reliability of the instrument. The Cronbach Alpha for the instrument constructs of entrepreneurial self-efficacy (0.8960) and entrepreneurship (0.9052), both of which exceed the minimum requirement $\geq 0.70$ to verify internal consistency. The factor loadings for each item for both constructs range from 0.539 to 0.941 , which are generally very practical to be sustained for subsequent analysis.

\section{Findings}

Frequency analysis shows that the 317 respondents consisted of 101 male students $(31.9 \%)$ and 216 female students $(68.1 \%)$. According to educational background, 228 students $(71.9 \%)$ are non-technical students in fields such as commerce, tourism, and hospitality. Meanwhile, the remaining 89 respondents are technical students (28.1\%). A total of 234 respondents (73.8\%) have business backgrounds through immediate family, other relatives, friends, or other personal contacts. Of the total number of respondents, 237 students $(74.8 \%)$ have participated in entrepreneurship courses.

\subsection{What is the Level of Entrepreneurial Self-efficacy based on the Involvement of Students in Entrepreneurship Education?}

Table 2 shows that both groups, students who have participated in entrepreneurship courses $(\mathrm{M}=3.9201, \mathrm{SD}=$ $0.4395)$ and those who have not $(\mathrm{M}=3.8433 \mathrm{SD}=0.4738)$, have high levels of entrepreneurship self-efficacy. Table 2 explains the distribution of self-efficacy levels for both 
groups of students based on their involvement in entrepreneurship education. With respect to generating new ideas and identifying market demand for products and services, students who received entrepreneurship education were found to have more self-confidence in their own abilities than students who never attended any entrepreneurship education programs.

Information on detailed feedback of entrepreneurial self-efficacy of both groups of students is shown in Table 3. Data reports that every entrepreneurial self-efficacy item shows the highest percentage of Strongly Agree (SA) responses. Students who were involved in entrepreneurship education programs appear to possess the skills of all elements related to entrepreneurial self-efficacy. They have higher confidence in their ability to ensure that other people understand and believe in the vision and planning of developing a new business and feel they are capable of forming effective marketing or advertising for a new product or service. This group of students also feels they can form business networks, and share information with other people, and can accurately and explicitly explain their business ideas either verbally orally or in writing.

Table 3 shows that even though both categories of students show high level of confidence in their skill to manage human resources, it was found that the group of students who have participated in entrepreneurship education feels more capable in managing, recruiting, and paying employees as well as distributing jobs to their employees and overcoming business crises effectively. Furthermore, this group of students also believes that they can inspire, encourage, train, and motivate their employees.

Table 2. Level of entrepreneurial self-efficacy based on students' involvement in entrepreneurship education

\begin{tabular}{cccccc}
\hline & Involvement in entrepreneurship & $\mathrm{n}$ & Mean & SD & Description \\
\hline \multirow{2}{*}{ ESE } & Have been involved & 237 & 3.9201 & 0.4395 & High \\
& Never been involved & 80 & 3.8433 & 0.4738 & High \\
\hline
\end{tabular}

Note: ESE = Entrepreneurial Self - Efficacy

Table 3. Details of the level of entrepreneurial self-efficacy distribution based on students' involvement in entrepreneurship education

\begin{tabular}{|c|c|c|c|c|c|c|c|c|}
\hline \multirow[b]{2}{*}{ Items } & \multirow{2}{*}{$\begin{array}{l}\text { Involvement in } \\
\text { Entrepreneurship Education }\end{array}$} & \multirow[b]{2}{*}{$\mathrm{n}$} & \multicolumn{2}{|c|}{$\mathrm{SD}+\mathrm{D}$} & \multicolumn{2}{|c|}{ SOD } & \multicolumn{2}{|c|}{$\mathrm{A}+\mathrm{SA}$} \\
\hline & & & Frequency & $\begin{array}{c}\text { Percentage } \\
(\%)\end{array}$ & Frequency & $\begin{array}{c}\text { Percentage } \\
(\%)\end{array}$ & Frequency & $\begin{array}{c}\text { Percentage } \\
(\%)\end{array}$ \\
\hline \multirow{2}{*}{ ESE1 } & Have Been Involved & 237 & 10 & 4.2 & 61 & 25.7 & 166 & 70.1 \\
\hline & Never Been Involved & 80 & 3 & 3.8 & 23 & 28.8 & 54 & 67.5 \\
\hline \multirow{2}{*}{ ESE2 } & Have Been Involved & 237 & 2 & 0.8 & 49 & 20.7 & 186 & 78.5 \\
\hline & Never Been Involved & 80 & 3 & 3.8 & 22 & 27.5 & 55 & 68.8 \\
\hline \multirow{2}{*}{ ESE6 } & Have Been Involved & 237 & 10 & 4.2 & 68 & 28.7 & 159 & 67.1 \\
\hline & Never Been Involved & 80 & 1 & 1.3 & 19 & 23.8 & 60 & 75.1 \\
\hline \multirow{2}{*}{ ESE7 } & Have Been Involved & 237 & 9 & 3.8 & 57 & 24.1 & 171 & 72.1 \\
\hline & Never Been Involved & 80 & 5 & 6.3 & 21 & 26.3 & 54 & 67.5 \\
\hline \multirow{2}{*}{ ESE8 } & Have Been Involved & 237 & 4 & 1.7 & 50 & 21.1 & 183 & 77.3 \\
\hline & Never Been Involved & 80 & 5 & 6.3 & 14 & 17.5 & 61 & 76.3 \\
\hline \multirow{2}{*}{ ESE9 } & Have Been Involved & 237 & 2 & 0.8 & 31 & 13.1 & 204 & 86.1 \\
\hline & Never Been Involved & 80 & 2 & 2.6 & 15 & 18.8 & 63 & 78.8 \\
\hline \multirow{2}{*}{ ESE10 } & Have Been Involved & 237 & 4 & 1.7 & 47 & 19.8 & 186 & 78.5 \\
\hline & Never Been Involved & 80 & 2 & 2.5 & 24 & 30 & 54 & 67.5 \\
\hline \multirow{2}{*}{ ESE11 } & Have Been Involved & 237 & 11 & 4.6 & 33 & 13.9 & 193 & 81.4 \\
\hline & Never Been Involved & 80 & 4 & 5 & 26 & 32.5 & 50 & 62.5 \\
\hline \multirow{2}{*}{ ESE12 } & Have Been Involved & 237 & 12 & 5 & 51 & 21.5 & 174 & 73.4 \\
\hline & Never Been Involved & 80 & 5 & 6.3 & 21 & 26.3 & 54 & 67.6 \\
\hline \multirow{2}{*}{ ESE13 } & Have Been Involved & 237 & 4 & 1.7 & 27 & 11.4 & 206 & 86.9 \\
\hline & Never Been Involved & 80 & 2 & 2.5 & 14 & 17.5 & 64 & 80.1 \\
\hline \multirow{2}{*}{ ESE14 } & Have Been Involved & 237 & 5 & 2.1 & 54 & 22.8 & 178 & 75.1 \\
\hline & Never Been Involved & 80 & 2 & 2.5 & 28 & 35 & 50 & 62.6 \\
\hline \multirow{2}{*}{ ESE15 } & Have Been Involved & 237 & 7 & 2.9 & 22 & 9.3 & 208 & 87.8 \\
\hline & Never Been Involved & 80 & 3 & 3.8 & 11 & 13.8 & 66 & 82.6 \\
\hline \multirow{2}{*}{ ESE16 } & Have Been Involved & 237 & 6 & 2.5 & 22 & 9.3 & 209 & 88.2 \\
\hline & Never Been Involved & 80 & 2 & 2.6 & 19 & 23.8 & 59 & 73.8 \\
\hline \multirow{2}{*}{ ESE17 } & Have Been Involved & 237 & 12 & 5 & 46 & 19.4 & 179 & 75.5 \\
\hline & Never Been Involved & 80 & 1 & 1.3 & 17 & 21.3 & 62 & 77.5 \\
\hline \multirow{2}{*}{ ESE18 } & Have Been Involved & 237 & 9 & 3.8 & 41 & 17.3 & 187 & 78.9 \\
\hline & Never Been Involved & 80 & 2 & 2.5 & 11 & 13.8 & 67 & 83.8 \\
\hline
\end{tabular}


From a financial management perspective, the majority of the group of students who have never been involved in entrepreneurship education agree that they are capable of organizing and maintaining their business financial records and managing business assets as opposed to students who have had any entrepreneurship education. For example, in planning a business, it was found that the group of students who have never been involved in any entrepreneurship education programs are more likely to believe that they could predict the total capital needed to start a business. This result is in line with a study by [51] towards polytechnic students with high level of self-efficacy (Mean $=3.92$, Standard deviation $=0.58$ ).

\subsection{What is the Level of Entrepreneurial Intention Based on the Student's Involvement in Entrepreneurship?}

Table 4 shows that both groups of students have a high level of entrepreneurial intention $(\mathrm{M}=3.5074, \mathrm{SD}=$ $0.9568, \mathrm{M}=3.6563, \mathrm{SD}=0.8682$ ). Table 5 shows the analysis of the respondents' intention level towards involvement in entrepreneurship and business within five years after graduation. Even though both groups may show the same level of entrepreneurial intention in terms of interest, consideration, and possibility of becoming an entrepreneur immediately after graduation, Table 5 explains that the group of students who never attended any entrepreneurship courses tend to choose entrepreneurship five years after graduating from a polytechnic institution.

Table 4. Level of entrepreneurial intention based on students' involvement in entrepreneurship education

\begin{tabular}{cccccc}
\hline & $\begin{array}{c}\text { Involvement in } \\
\text { entrepreneurship }\end{array}$ & $\mathrm{n}$ & Mean & SD & Description \\
\hline EI & Have been involved & 237 & 3.5074 & 0.9568 & High \\
& Never been involved & 80 & 3.6563 & 0.8682 & High \\
\hline
\end{tabular}

Note: $\mathrm{EI}=$ Entrepreneurial Intention

\section{Discussion and Conclusion}

The findings show that the level of entrepreneurial self-efficacy of students who received some form of entrepreneurship education is similar to those who have not. However, students who have been involved in entrepreneurship educational courses in polytechnic institutions in Malaysia show a slightly higher level of entrepreneurial self-efficacy compared to students who have never been exposed to entrepreneurial knowledge, especially in the aspects of generating business ideas, business planning, building business networks, and managing human resources. This finding is in line with [20], based on [38] theory, and supports the idea that the educational system can improve students' self-efficacy through its role in mastery experience, vicarious experience, social persuasion, and psychological states.

Furthermore, it cannot be denied that entrepreneurship education plays a role in providing skills and knowledge to students that will prove useful as they enter entrepreneurship and the business world. The findings of the study show that polytechnic diploma students in both groups have only a moderate level of entrepreneurial intention. This demonstrates that even students who have never participated in any entrepreneurship educational courses appear to have interests in entrepreneurship and are prepared to consider it as their career choice immediately after graduating. This finding is in line with studies by [43-45] who found that entrepreneurship education in higher institutions does not influence the involvement of graduates in the world of entrepreneurship. We have to note that any individual who never experiences the real entrepreneurial environment will not be able to understand what entrepreneurship is about. It is not just simply transaction between buyer and seller. This is explained by the study of [52] which found significant relationship between the knowledge of entrepreneurial support and the entrepreneurial intention.

Table 5. Details of the level of entrepreneurial intention distribution based on students' involvement in entrepreneurship education

\begin{tabular}{|c|c|c|c|c|c|c|c|c|}
\hline \multirow[b]{2}{*}{ Items } & \multirow{2}{*}{$\begin{array}{l}\text { Involvement in } \\
\text { Entrepreneurship } \\
\text { Education }\end{array}$} & \multirow[b]{2}{*}{$\mathrm{n}$} & \multicolumn{2}{|c|}{$\mathrm{SD}+\mathrm{D}$} & \multicolumn{2}{|c|}{ SOD } & \multicolumn{2}{|c|}{$\mathrm{A}+\mathrm{SA}$} \\
\hline & & & Frequency & $\begin{array}{c}\text { Percentage } \\
(\%)\end{array}$ & Frequency & $\begin{array}{c}\text { Percentage } \\
(\%)\end{array}$ & Frequency & $\begin{array}{c}\text { Percentage } \\
(\%)\end{array}$ \\
\hline \multirow{2}{*}{ EI1 } & Have Been Involved & 237 & 141 & 59.5 & 53 & 22.4 & 30 & 18.2 \\
\hline & Never Been Involved & 80 & 49 & 61.3 & 20 & 25 & 11 & 13.8 \\
\hline \multirow{2}{*}{$\mathrm{EI} 2$} & Have Been Involved & 237 & 127 & 53.6 & 75 & 31.6 & 35 & 39.8 \\
\hline & Never Been Involved & 80 & 47 & 58.8 & 27 & 33.8 & 6 & 7.6 \\
\hline \multirow{2}{*}{$\mathrm{EI} 3$} & Have Been Involved & 237 & 101 & 42.6 & 91 & 38.4 & 45 & 19.0 \\
\hline & Never Been Involved & 80 & 35 & 43.8 & 36 & 45.0 & 9 & 11.3 \\
\hline \multirow{2}{*}{ EI4 } & Have Been Involved & 237 & 132 & 55.7 & 66 & 27.8 & 39 & 16.5 \\
\hline & Never Been Involved & 80 & 36 & 45 & 35 & 43.8 & 9 & 11.3 \\
\hline
\end{tabular}


Hence, the primary implication from this study is that the entrepreneurship education being offered in polytechnic institutes should be reviewed to ensure that this trend is reversed and that the programs ultimately achieve the objectives envisioned by the DPCCE. One of the suggestions is to set a moderate sales target in practical skills of entrepreneurship course. Higher goals and target force the student to desperately venture a business and make the profit than properly learning the right way to start a business. In addition, the entrepreneurship course should imply how to improve and maintain the business stages such as survival, success, take-off and resource maturity stages and not only focusing on existence of the business [53]. It is because the risk of business failure often hinders an individual to venture a business. A study by [54] found that students are less confident to take risks related to entrepreneurship. [18] also found that students are less confident about whether they are able to tolerate and manage the uncertainties that exist in business. Most students do not dare to take risks even though they have an interest and are positive towards entrepreneurial careers. This is because students are very afraid to make mistakes and bear the risk of failure [54].

Our study suffers from certain limitations. There is a possibility that students may choose entrepreneurial careers after a longer period of time; however, this study only focused on the level of entrepreneurial intention in the short term. This is in line with a statement by [55] that asserted that entrepreneurship education has more long-term effects on entrepreneurial intention than short-term effects. In addition, there are many other factors that influence students about choosing entrepreneurship as a career path after graduation. One of the factors is educational background [56]. It shows that students in non-technical fields who have any involvement with entrepreneurship education have a higher tendency to become entrepreneurs within a short period of time after graduation compared to students in more technical fields who have also participated in entrepreneurship education programs.

\section{Acknowledgments}

The authors would like to thank the Faculty of Education, Universiti Kebangsaan Malaysia for funding the research grant GG-2019-036.

\section{REFERENCES}

[1] Ministry of Entrepreneur Development and Cooperatives (MEDAC), "National Entrepreneurship Policy 2030", Malaysia, pp.1 - 78, 2019. http://www.medac.gov.my /admin/files/med/image/portal/Dasar\%20Keusahawanan $\% 2$
0Nasional\%20(DKN)\%202030.pdf (accessed Apr 15, 2020).

[2] Ministry of Higher Education (MoHE), "Entrepreneurship Action Plan of Higher Education Institutions (2016-2020)", Malaysia, pp. 7, 2016, https://www.moe.gov.my/ menumedia/media-cetak/penerbitan/pelan-tindakan-keusaha wanan-ipt-2016-2020/1354-pelan-tindakan-keusahawanan-i pt-2016-2020/file (accessed Apr 15, 2020).

[3] Ministry of Higher Education (MoHE), "Bilangan Kemasukan, Enrolmen dan Keluaran Sepenuh Masa Mengikut Peringkat Pengajian Berdasarkan Politeknik (2014-2015)", Malaysia.https://www.mohe.gov.my/en/dow nload/awam/statistik/2015/220-bab-4-politeknik-1/file (accessed Apr 15, 2020).

[4] Zainudin, M.Z. "Kecenderungan Ke Arah Meningkatkan Budaya Keusahawanan di Kalangan Pelajar Politeknik Banting, Selangor", Konvensyen Keusahawanan Politeknik Malaysia, Kota Bharu, 14-17 Nov. 2015, pp. 1-12. DOI: 10.13140/RG.2.1.4109.1444.

[5] Ministry of Higher Education (MoHE), "Graduates Tracer Study 2018”, Malaysia, pp. 57, 2019, https:/www.moe.gov.my/en/muat-turun/laporan-dan-statist $\mathrm{ik} /$ pendidikan-tinggi/laporan-kajian-pengesanan-graduan/20 18-11/3157-laporan-kajian-pengesanan-graduan-2018/file (accessed Apr 15, 2020).

[6] Nasaruddin, N. \& Othman, N. "Evaluation of Polytechnic Entrepreneurship Programs in Malaysia", International Journal of Trade, Economics and Finance, vol. 3, no. 5, pp. 356-362, 2012. DOI: 10.7763/IJTEF.2012.V3.227.

[7] Mansor, M. "Keberkesanan Pembelajaran Berasaskan Konsultasi dalam Pemupukan Budaya Keusahawanan dalam Kalangan Pelajar Politeknik", PhD Thesis. Universiti Kebangsaan Malaysia, 2014.

[8] Yusoff, A \& Marsim, S., "Promoting Entrepreneurial Competencies via Education: Is Malaysian Polytechnic Entrepreneurship Education Effective?" International Journal of Business and Management, vol. 2, pp. 29-35, 2018. DOI: 10.26666/rmp.ijbm.2018.4.5.

[9] Campo, J., "Analysis of the Influence of Self-Efficacy on Entrepreneurial Intentions," in Prospectiva, vol. 9, no. 2, 2011, pp. 14-21.

[10] Densberger, K., "The Self-Efficacy and Risk-Propensity of Entrepreneurs," Journal of Enterprising Culture, vol. 22, no. 4, pp. 437-462, 2014. https://doi.org/10.1142/S0218495814 500186.

[11] Adnyana, G.L.A.\& Purnami, N.M., "Pengaruh Pendidikan Kewirausahaan, Self Efficacy dan Locus of Control Pada Niat Berwirausaha," E-Jurnal Manajemen Unud, vol. 5, no. 2, pp. 1160-1188, 2016.

[12] Zailani, S., Iranmanesh, M., Nikbin, D. \& Jumadi, H.B., "Determinants and Environmental Outcome of Green Technology Innovation Adoption in the Transportation Industry in Malaysia," Asian Journal of Technology Innovation, vol. 22, no. 2, pp. 286-301, 2014.

[13] Nursito, S.\& Nugroho, A.J.S., “Analisis Pengaruh Interaksi Pengetahuan Kewirausahaan dan Efikasi Kendiri Terhadap Intensi Kewirausahaan," Kiat Bisnis, vol. 5, no.3, pp. 148-158, 2013. 
[14] Riyanti. B.P.D., "Kewirausahaan Bagi Mahasiswa," 1st ed. Jakarta: Fakultas Psikologi Unika Atma Jaya, 2009.

[15] Wu, S. \& Dagher, G.K., "Need for Achievement, Business Goals and Entrepreneurial Persistence," Management Research News, vol. 30, no. 12, pp. 928-941, 2007. DOI: $10.1108 / 01409170710833358$.

[16] Kessler, A., Korunka, C., Frank, H. \& Lueger, M., "Predicting Founding Success and New Venture Survival: A Longitudinal Nascent Entrepreneurship Approach," Journal of Enterprising Culture, vol. 20, no. 1, pp. 25-55, 2012. https://doi.org/10.1142/S0218495812500021

[17] Sangeeta, B.B., "10 Talents That Drive Entrepreneurial Success," in Entrepreneurial Strengths Finder, Gallup Business Journal, 2014, pp. 132-143.

[18] Setiawan, J.L., "Examining Entrepreneurial Self-efficacy among Students," The 5th Indonesia International Conference on Innovation, Entrepreneurship, and Small Business (IICIES 2013), 115, pp. 235-242, 2013. https://doi.org/10.1016/j.sbspro.2014.02.431

[19] Yurtkoru, E. S., Acar, P., \& Teraman, B. S., "Willingness to Take Risk and Entrepreneurial Intention of University Students: An Empirical Study Comparing Private and State Universities," 10th International Strategic Management Conference. Procedia - Social and Behavioral Science, vol. 150, pp. 834 - 840, 2014. https://doi.org/10.1016/j.sbspro.2 014.09 .092

[20] Zhao, H., Seibert, S. E., \& Hills, G. E., "The Mediating Role of Self-Efficacy in the Development of Entrepreneurial Intentions," Journal of Applied Psychology, vol. 90, no. 6, pp. 1265-1272, 2005. DOI: 10.1037/0021-9010.90.6.1265

[21] Krueger, N. F., Reilly, M.D., \& Carsrud, A.L., "Competing Models of Entrepreneurial Intentions," Journal of Business Venturing, vol. 15, no. 5/6, pp. 411-432, 2000. https://doi.org/10.1016/S0883-9026(98)00033-0

[22] Pihie, Z., "Entrepreneurship as a Career Choice: An Analysis of Entrepreneurial Self-Efficacy and Intention of University Students," European Journal of Social Sciences, vol. 9, no. 2, pp. 338-349, 2009.

[23] Remeikiene, R., Startiene, G., \& Dumciuviene, D., "Explaining Entrepreneurial Intention of University Students: The Role of Entrepreneurial Education," International Conference 2013, pp. 299-307.

[24] Ajzen, I., "Chapter 2: From Intentions to Actions: A Theory of Planned Behavior," in J. Kuhl et al (ed). Action Control. Springer-Velag Berlin Heidelberg, 1985.

[25] Fishbein, M. \& Ajzen, I., "Belief, Attitude, Intention and Behavior: An Introduction to Theory and Research," Addison-Wesley, MA, 1975.

[26] Ajzen, I., "The Theory of Planned Behavior" Organizational Behavior and Human Decision Processes, vol. 50, no. 2, pp. 179-211, 1991.

[27] Liñán, F. \& Chen, Y. W., "Testing the Entrepreneurial Intention Model on a Two-Country Sample," in Documents de Treball, Universitat Autònoma de Barcelona, Departament d'Economia de l'Empresa, 2006

[28] Chen, C, Greene, P., \& Crick, A., "Does Entrepreneurial Self-Efficacy Distinguish Entrepreneurs from Managers?"
Journal of Business Venturing, vol. 13. no. 4, pp. 295-316, 1998. https://doi.org/10.1016/S0883-9026(97)00029-3

[29] Dave, V., "An Effectuation Measure of Entrepreneurial Intent," Procedia Social and Behavior Sciences, vol. 169, pp. 131-142, 2015. https://doi.org/10.1016/j.sbspro.2015.01.294

[30] Mushtaq, H. A., Niazi, C.S.K., Hunjra, A.I. \& Rehman, K.U., "Planned Behavior Entrepreneurship and Intention to Create a New Venture among Young Graduates," Management \& Marketing Challenges for the Knowledge Society, vol. 6, no. 3, pp. 437-456, 2011. DOI: 10.2139/ssrn.1944685

[31] Ajzen, I., "Perceived Behavioral Control, Self-Efficacy, Locus of Control, and The Theory of Planned Behavior," Journal of Applied Social Psychology, vol. 32, no. 4, pp. 665-685, 2002. https://doi.org/10.1111/j.1559-1816.2002.tb 00236.x

[32] Bandura. A., "Self-Efficacy: The Exercise of Control," New York: W.H. Freeman and Company. 1997.

[33] Cassar, G \& Friedman, H.L., "Does Self-Efficacy Affect Entrepreneurial Investment?" Strategic Entrepreneurship Journal, vol. 3, no. 30, pp. 241-260, 2009. DOI: $10.1002 /$ sej. 73

[34] Hechavarria, D.M. Renko, M.\& Matthews, C.H., "The Nascent Entrepreneurship Hub: Goals, Entrepreneurial SelfEfficacy and Start-up Outcomes," Small Business Economics, vol. 39, no. 3, pp. 1-17, 2012. DOI: $10.1007 / \mathrm{s} 11187-011-9355-2$

[35] De Noble. A.. Jung. D.. \& Ehrlich. S., "Entrepreneurial Self Efficacy: The Development of a Measure and Its Relationship to Entrepreneurial Action," in Frontiers of Entrepreneurship Research. Wellesley, MA: Babson College, pp. 73-87, 1999.

[36] McGee. J.E., Peterson. M., Mueller. S.L., \& Sequeira. J.M., "Entrepreneurial Self-Efficacy: Refining the Measure," Entrepreneurship Theory and Practice, vol. 33. no. 4, pp. 965-988, 2009. https://doi.org/10.1111/j.1540-6520.2009.0 0304.x

[37] Mueller, S. \& Goic, S., "East-West Differences in Entrepreneurial Self-Efficacy: Implications for Entrepreneurship Education in Transition Economies," International Journal of Entrepreneurship Education, vol. 1, no. 4, pp. 613-632, 2003.

[38] Bandura, A., "Social Foundations of Thought and Action: A Social Cognitive"" in Englewood Cliffs, NJ: Prentice Hall, Edition xiii, 1986, pp. 617.

[39] Merle, K., Marianne, K., Urve, V. \& Aino, K., "Entrepreneurship Education at University Level and Students' Entrepreneurial Intentions," Contemporary Issues in Business, Management and Education 2013, Procedia Social and Behavioral Sciences. vol. 110, pp. 658-668, 2013. https://doi.org/10.1016/j.sbspro.2013.12.910

[40] Zhang, Y., Duysters, G., \& Cloodt, M., "The Role of Entrepreneurship Education as a Predictor of University Students' Entrepreneurial Intention," International Entrepreneurship and Management Journal, vol. 10, no. 3, pp. $623-641,2014$. DOI: $10.1007 / \mathrm{s} 11365-012-0246-\mathrm{Z}$

[41] Sondari, M.C., "Is Entrepreneurship Education Really Needed? Examining Antecedent of Entrepreneurial Career Intention," The 5th Indonesia International Conference on 
Innovation, Entrepreneur and Small Business (IICIES 2013), Procedia Social and Behavioral Sciences, vol. 115, pp. 44-53, 2014. https://doi.org/10.1016/j.sbspro.2014.02.414

[42] Hussain, A. \& Hashim, N., "The Impact of Entrepreneurial Alertness on Entrepreneurial Intentions," Journal of International Business Research and Marketing, vol. 1, no. 6, pp. 7-11, 2015. DOI: $10.18775 /$ jibrm. 1849-8558.2015.16.3 001

[43] Saeed, S., Yousafzi, S.Y., Yani-De-Soriano, M. \& Muffatto, M., "The Role of Perceived University Support in the Formation of Students' Entrepreneurial Intention," Journal of Small Business Management, Vol. 53, No. 4, 1127-1145, 2015. https://doi.org/10.1111/jsbm.12090

[44] Hamzah, H., Yahya, Z., Sarip, A.G \&Adnan, Y. M., "Impact of Entrepreneurship Education Programme (EEP) on Entrepreneurial Intention of Real Estate Graduates," Pacific Rim Property Research Journal, vol. 22, no. 1, pp. 1-13, 2016. DOI: $10.1080 / 14445921.2016 .1158897$

[45] Wahid. H., Norashidah, H.,\& Amlus, I., "Hubungan Persekitaran Universiti Terhadap Niat Keusahawanan Dalam Kalangan Pelajar Keusahawanan," Journal of Global Business and Social Entrepreneurship (GBSE), vol. 1,pp. 136-149, 2017.

[46] Barba-Sanchez, V. \& Atienza-Sahuquillo, C., "Entrepreneurial Intention among Engineering Students: The Role of Entrepreneurship Education," European Research on Management and Business Economics, vol. 24, no. 1, pp. 53-61, 2018. https://doi.org/10.1016/j.iedeen.201 7.04 .001

[47] Shamsudin, S.F., Al Mamun, A., Che Nawi, N., Nasir, A. \& Zakaria, M.N., "Factors Affecting Entrepreneurial Intention among The Malaysian University Students," Journal of Developing Areas, vol. 51, no. 4, pp. 423-431, 2017.

[48] Krejcie, R.V.\& Morgan, D.W., "Determining Sample Size for Research Activities," Educational and Psychology Measurement. 30, 607-610, 1970. https://doi.org/10.1177/0 01316447003000308
[49] Fincham, J. E., "Response Rates and Responsiveness for Surveys, Standards, and the Journal," American Journal for Pharmaceutical Education, Vol. 72. No. 2, 43, 2008. DOI: 10.5688/aj720243

[50] Drost, E., "Validity and Reliability in Social Science Research," Education Research and Perspectives, vol. 38, pp. 105-124, 2011.

[51] Amran, N., \& Radin A. Rahman, R. S. A., "Entrepreneurial efficacy and its Relations with Technopreneurial Intention among Engineering Students in Malaysian Polytechnic Institutions," Journal of Advanced Research in Dynamical \& Control Systems, vol. 10, no. 04, pp. 1625-1630, 2018.

[52] Malebana, M., "The Effect of Knowledge of Entrepreneurial Support on Entrepreneurial Intention," Mediterranean Journal of Social Sciences, Vol. 5, 1020-1028, 2014. DOI: 10.5901/mjss.2014.v5n20p1020

[53] Lewis, V. \& Churchill, N., The Five Stages of Small Business Growth. Harvard Business Review, 3, 1987. https://www.researchgate.net/publication/228315536_The Five_Stages_of_Small_Business_Growth (accessed A Apr 15, 2020).

[54] Nasharudin, N. \& Harun, H., “Aspirasi Kerjaya Keusahawanan dalam Kalangan Pelajar," Jurnal Pendidikan Malaysia. Vol. 35, pp. 11-17, 2010.

[55] Galloway, L \& Brown, W., "Entrepreneurship Education at University: A Driver in The Creation of High Growth Firms?" Education + Training, vol. 44, no. 8/9, pp. 398-405, 2002. DOI: $10.1108 / 00400910210449231$

[56] Yasin, A., Mahmood, N., \& Jaafar, N., "Students' Entrepreneurial Inclination at a Malaysian Polytechnic: A Preliminary Investigation," International Education Studies, vol. 4, no. 2, pp. 198-207, 2011. DOI: 10.5539/ies.v4n2p198

[57] Zain, Z.M; Akram, A.M., Ghani, E.K. "Entrepreneurship intention among Malaysian business students", Canadian Social Science, vol.6, no.3, pp.34-44, 2010 